DOI: 10.17707/AgricultForest.65.4.11

\author{
Dragana LALEVIĆ, Milan BIBERDŽIĆ, Zoran ILIĆ, \\ Lidija MILENKOVIĆ, Nadica TMUŠ́Ć, Jelena STOJILJKOVIĆ ${ }^{1}$
}

\title{
EFFECT OF CULTIVAR AND INCREASED NITROGEN QUANTITIES ON SOME PRODUCTIVE TRAITS OF TRITICALE
}

\begin{abstract}
SUMMARY
In the research carried out in the period from 2009-2012, in the north of Montenegro, the influence of cultivar and different amounts of nitrogen on the productive traits of winter triticale was examined. The research covered 5 cultivars of winter triticale (Odyssey, Kg-20, Triumph, Rtanj and Tango). The experiment was set up by random block system in four repetitions. Unfertilized plot (the control) and three steps of $\mathrm{N}$ fertilization (60, 90 and $120 \mathrm{~kg} \mathrm{ha}^{-1} \mathrm{~N}$ ) on the same level of phosphorus and potassium $\left(80 \mathrm{~kg} \mathrm{ha}^{-1} \mathrm{P}_{2} \mathrm{O}_{5}+80 \mathrm{~kg} \mathrm{ha}^{-1} \mathrm{~K}_{2} \mathrm{O}\right)$ were applied.

The results showed that genotypes respond to the application of mineral nutrients, as well as to the increased nitrogen levels by changing productive properties.

Variety Tango had the highest average grain yield, while Kg-20 had the lowest. Also, Tango had the highest value of the 1000 grain weight, while variety Triumph had the highest value of hectolitre weight. The application of fertilizers has led to a very large and significant increase of yield compared to the control. Based on the analysis of variance, it can be concluded that there were highly significant differences in grain yield among years of the research and significant differences at the 1000 grain weight and hectolitre weight.
\end{abstract}

Key words: fertilization, yield components, variety, winter triticale.

\section{INTRODUCTION}

Triticale, a hybrid species created by crossbreeding wheat and rye, is a promising species that takes a significant place in both crop and livestock production. As a species, it exhibited high adaptability in our agroecological conditions, which resulted in stable yields. Triticale is suitable for cultivation at higher altitudes, on soils with poor physicochemical properties, saline and acidic soil with pronounced resistance to biotic and abiotic stresses (Epure et al. 2015; Fras et al. 2016). According to the results of Stošović (2009), triticale achieved high yields in the hilly-mountainous region and in the application of lower cultivation technology, while under optimal conditions, in terms of grain yield, it

\footnotetext{
${ }^{1}$ Dragana Lalević *(corresponding author: dragana.lalevic@pr.ac.rs), Milan Biberdžić, Zoran Ilić, Lidija Milenković, Nadica Tmušić, University in Pristina, Faculty of Agriculture, Kopaonička bb, 38232 Lešak, Jelena Stojiljković, Agriculture Advising and Consulting Department, Leskovac, Jug Bogdanova 8A, 16000 Leskovac, SERBIA

Notes: The authors declare that they have no conflicts of interest. Authorship Form signed online.
} 
has mostly reached the leading varieties of wheat, and outreached the varieties of rye, barley and oats (Biberdžić et al. 2012). Also, Estrada-Campuzano et al. (2012) point out that new cultivars of triticale achieve higher yields and show better adaptation to soil and climatic conditions compared to wheat.

The great possibility of using triticale for different purposes, as well as the emphasized varietal differences, require the need and importance of more detailed studying of new varieties, with the aim of their more efficient utilization in wide production. Triticale plants, which are characterized by very rapid growth and development, are adaptable to different cultivation technologies and achieve high and stable grain yields (Kendal and Sayar 2016).

Different cultivars have different requirements for applying agrotechnical measures. Nitrogen is an element that has the greatest influence on the vegetative growth of the plant, its photosynthetic capacity and yield. Also, nitrogen positively affects the activity of the root system and its penetration into deeper soil layers. However, it makes a big difference for the plants in what ration they will adopt the necessary elements. It is known that increasing the amount of nitrogen in the soil increases the needs of plants for phosphorus and potassium, and the needs of plants for mineral elements vary greatly depending on climatic factors, primarily from precipitation (Biberdžić et al. 2011).

Popović et al. (2011), Jelić et al. (2013) and Rajičić et al (2019) underlined that mineral fertilizers play a vital role in increasing crop yields, but one of the main constraints in achieving proven crop potential is an unbalanced use of nutrients, in particular a low use of phosphorus in comparison to nitrogen. The optimum rate of phosphorus is important for grain yields improving. Djekić et al. (2014) pointed out that the lack of nutrients in the soil causes shortening of the period of grain and grain filling, which has a negative effect on the yield and quality of grain.

Cultivars of triticale are distinguished by high genetic potential for yield, and that is why triticale can be considered a perspective plant species, especially from the point of view of climate change, which through increasing temperatures and drought show an even more intense influence on cultivated plants. For this reason, it is necessary to spread species, such as triticale, that are more tolerant to stress conditions, in the production.

The aim of this research was to study the influence of the increased nitrogen levels on the productive properties on the tested cultivars, for this area a relatively new plant species. Also, the goal was to distinguish those cultivars of triticale which, under certain conditions of growth, give the highest yield of grain and the best quality.

\section{MATERIAL AND METHODS}

The three-year experiment (2009-2012) was carried out in the agroecological conditions of the north of Montenegro in the vicinity of Bijelo Polje (Sutivan) $\left(43^{\circ} 09^{\prime} \mathrm{N}, 19^{\circ} 77^{\prime} \mathrm{E}\right)$. The soil on which the experiment was carried out belongs to the type of Eutric Cambisol (CM-eu) on alluvial coating. 
The experiment was set up by random block system in four repetitions, with the size of an elementary plot of $6 \mathrm{~m}^{2}(3 \times 2 \mathrm{~m})$, including 5 cultivars (Odyssey, Kg-20, Triumph, Rtanj and Tango) of winter triticale ( $\times$ Triticosecale Wittmack). The study included the following varieties of fertilizers: unfertilized plot ( 0 - the control) and three variants of fertilization $\left(\mathrm{N}_{1}-60 \mathrm{~kg} \mathrm{ha}^{-1} \mathrm{~N}, 80 \mathrm{~kg} \mathrm{ha}^{-1} \mathrm{P}_{2} \mathrm{O}_{5}, 80\right.$ $\mathrm{kg} \mathrm{ha}^{-1} \mathrm{~K}_{2} \mathrm{O} ; \mathrm{N}_{2}-90 \mathrm{~kg} \mathrm{ha}^{-1} \mathrm{~N}, 80 \mathrm{~kg} \mathrm{ha}^{-1} \mathrm{P}_{2} \mathrm{O}_{5}, 80 \mathrm{~kg} \mathrm{ha}^{-1} \mathrm{~K}_{2} \mathrm{O}$ and $\mathrm{N}_{3}-120 \mathrm{~kg}$ $\mathrm{ha}^{-1} \mathrm{~N}, 80 \mathrm{~kg} \mathrm{ha}^{-1} \mathrm{P}_{2} \mathrm{O}_{5}, 80 \mathrm{~kg} \mathrm{ha}^{-1} \mathrm{~K}_{2} \mathrm{O}$ ). Phosphorus and potassium were used in equal amounts $\left(80 \mathrm{~kg} \mathrm{ha}^{-1}\right)$ before the sowing period, while nitrogen was used in small amounts before the sowing period, and the rest of the planned amount was used as fertilization at the end of March. Common agronomical practices were used in the experiment. Sowing was carried out by manual method in optimal term (second decade of October). At full maturity, a random sample of 30 plants was collected from each plot for hectoliter weight and 1000 grain weight measurements. Grain yield was determined after the harvest. Upon harvest, the grain yield of each plot was measured and calculated as $t \mathrm{ha}^{-1}$.

\section{Soil and weather conditions}

Before setting up the experiment, soil sampling was carried out from two depths from 0 to $10 \mathrm{~cm}$ and from 10 to $30 \mathrm{~cm}$. Samples were analysed in the Agrochemical Laboratory of the Centre for Cereal Grains in Kragujevac. The applied soil testing methods were adopted by the Yugoslav Society for Soil Studies (JDPZ). In the tested soil samples, which were pre-dried to air-dry state and crushed in a porcelain mortar to a particle size of $2 \mathrm{~mm}$, the following chemical and physical properties were determined: land reaction ( $\mathrm{pHKCl}$ ) by the combined glass electrode, the content of humus by the Kotzman method, content of $\mathrm{CaCO}_{3}$ volumetric, using Scheibler calcimeter (Džamić et al., 1996) and the content of the easy-access P and K by the Al-method, by Egner-Riehm (1960). The obtained results showed that the tested soil had an acid reaction, well supplied by humus 3.35-3.96\% and poor in available phosphorus (5.12-4.24 mg $100 \mathrm{~g}^{-1}$ soil) and potassium (7.5-3.8 mg $100 \mathrm{~g}^{-1}$ soil). The soil was weakly calcareous, too (the total content of carbonate being $2.4-2.44 \%$ ).

Meteorological conditions, temperature and precipitation are the main nongenetic factors that determine the success of cultivation of winter triticale and other small grains. In the growing season 2009-2010 there were $881 \mathrm{~mm}$ of rainfall which is $116 \mathrm{~mm}$ more than in the second year and $329 \mathrm{~mm}$ more compared to the third year of the research.

Figure 1 showed that in the period from October to July 2009-2010, the highest rainfall was recorded in October, and the lowest in June. In this same interval during 2010-2011, the highest rainfall was in December, and the lowest in March, while in the third year of the study the highest precipitation was recorded in February, and the lowest in November. From the above it can be concluded that conditions for germination and autumn plant development were considerably favourable during the first two years compared to the third year of research. Also, the amount of rainfall in the period from April to June in the first year of research was higher compared to the other two years of research. 


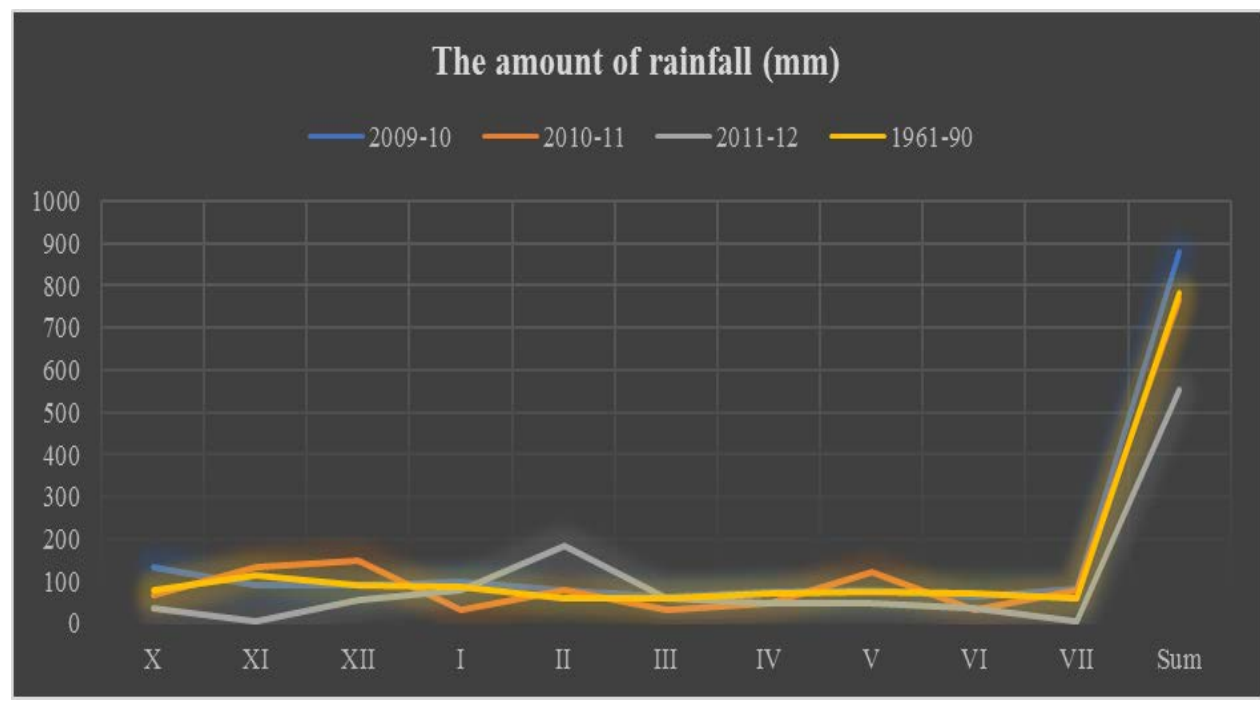

Figure 1. Rainfall distribution during the growing seasons (2009-2012) and multi-year average

Unlike the first two years of the study, in the second decade of November in 2011, air temperatures were significantly lower, which slowed down the development of plants in the initial stages (Fig. 2).

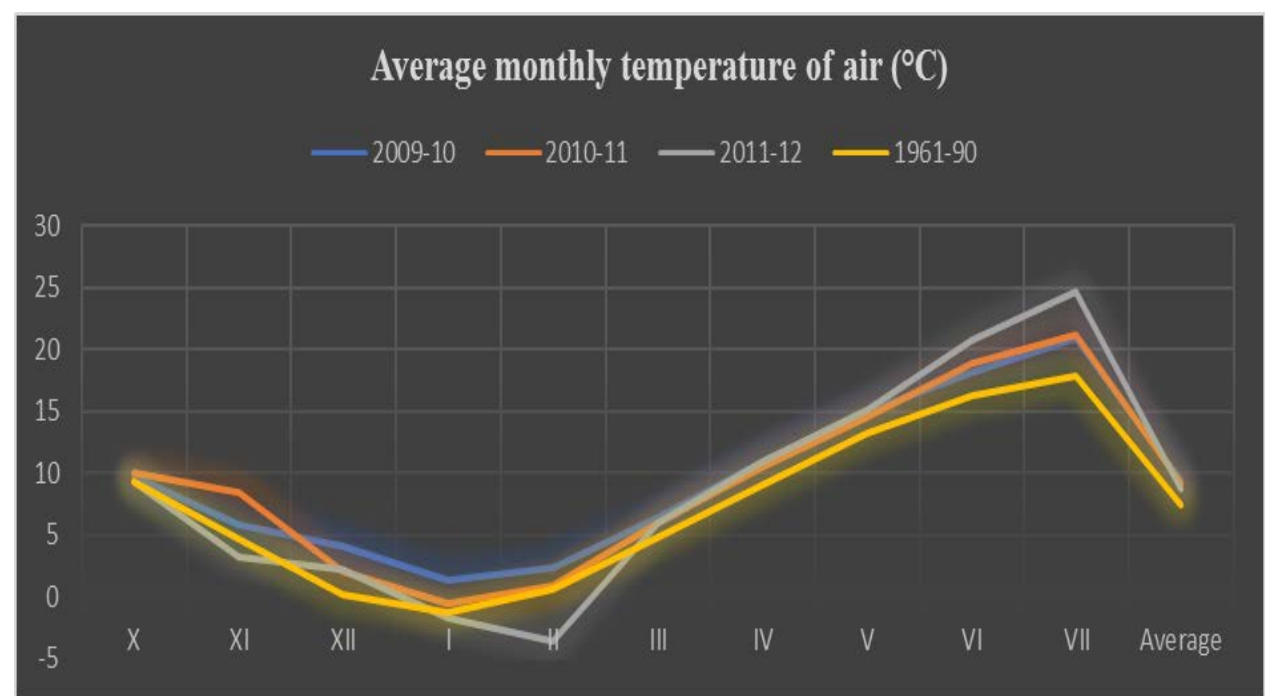

Figure 2. Middle monthly air temperature during the growing seasons (20092012) and multilevel average (1961-1990)

The biggest differences were observed in the coldest months, December, January and February. In February 2012, a lot of low temperatures were observed, especially in the first decade, when the temperature was $-9.6^{\circ} \mathrm{C}$. The 
snow cover in this year has significantly contributed to the protection of plants from freezing, but its long retention slowed down the vegetation in the spring.

The favourable air temperatures in May and June, in the first two years of the study, followed by a satisfactory amount of precipitation allowed the proper formation and filling of grains in relation to the third year. The high air temperatures in July 2012 with the modest moisture reserves led to distortion of the filling phase and forced ripening, which had a negative impact on the yield.

\section{Computation and data analysis}

Analysis of variance (ANOVA) was performed using the WASP 1.0. statistical package with two-way factors, fertilization and variety, to establish the treatment effects. The importance of differences among the observed elements was tested by Fisher's protected least significant difference (LSD) test at $\mathrm{P} \leq 0.05$ and $\mathrm{P} \leq 0.01$.

\section{RESULTS AND DISCUSSION}

The results of our research have shown that there are significant differences in the values of 1000 grain weight among the tested triticale cultivars (Table 1.). Also, it was noted that the conditions of the external environment as well as the certain nutritional elements significantly influenced the observed trait. The application of the highest nitrogen dose in combination with phosphorus and potassium, in all three years of the research, resulted in the highest average 1000 grain weight in all cultivars included in the study, which is in agreement with Jaćimović et al. (2008) who found that 1000 grain weight is significantly higher in intensive fertilization treatments, especially by nitrogen.

Our results are in agreement with the results of Djekić et al. (2010; 2012), Djurić et al. (2013) and Jelić et al. (2013) which pointed out that 1000 grain weight is a cultivar specific trait, with considerably higher variations being observed among genotypes than among treatments or factors of environment. Bielski et al. (2015), according to their research, pointed out that the application of nitrogen in the amount of $120 \mathrm{~kg}$ ha- 1 led to a significant decrease of 1000 grain weight compared to the application of nitrogen in the amount of $30 \mathrm{~kg}$ ha- 1 . However, the same author emphasized that the application of nitrogen in the amount of $150 \mathrm{~kg}$ ha-1 led slightly to the increase of 1000 grain weight.

The highest average 1000 grain weight in the three-year study period was achieved by the cultivar Tango (48.2 g), and the lowest by the cultivar Kg-20 (32.8 g). Also, the lowest 1000 grain weight was noted in the first year of the research (40.9 g), which was the climate most favourable, while the highest one was achieved in the third year (44.2 g). Climatic conditions are especially important during the filling of the grain, because the lack of moisture and high temperature during this period influence the reduction of the 1000 grains weight (Bielski 2015), which is confirmed by the results of this research. 
Lalević et al.

Table 1. 1000 grain weight (g) per cultivars, fertilizing variants and years

\begin{tabular}{|c|c|c|c|c|c|c|c|c|c|c|c|c|c|c|c|}
\hline \multicolumn{16}{|c|}{1000 grain weight $(\mathrm{g})$} \\
\hline \multirow{3}{*}{$\begin{array}{l}\text { Varieties } \\
\text { (A) }\end{array}$} & \multicolumn{5}{|c|}{$2009-2010$} & \multicolumn{4}{|c|}{$2010-2011$} & \multicolumn{6}{|c|}{$2011-2012$} \\
\hline & \multicolumn{13}{|c|}{ Fertilization variant (B) } & & \\
\hline & 0 & $\mathrm{~N}_{1}$ & $\mathrm{~N}_{2}$ & $\mathrm{~N}_{3}$ & Aver. & 0 & $\mathrm{~N}_{1}$ & $\mathrm{~N}_{2}$ & $\mathrm{~N}_{3}$ & Aver. & 0 & $\mathrm{~N}_{1}$ & $\mathrm{~N}_{2}$ & $\mathrm{~N}_{3}$ & Aver. \\
\hline Odyssey & 39.0 & 40.3 & 42.8 & 45.7 & 41.9 & 39.4 & 40.2 & 40.5 & 42.3 & 40.6 & 41.4 & 44.0 & 45.5 & 47.9 & 44.7 \\
\hline $\mathrm{Kg}-20$ & 27.0 & 31.7 & 32.9 & 33.4 & 31.6 & 30.7 & 35.7 & 31.3 & 34.6 & 33.1 & 28.8 & 31.8 & 35.8 & 38.1 & 33.6 \\
\hline Triumph & 38.2 & 41.8 & 40.6 & 45.1 & 41.4 & 39.0 & 40.7 & 41.2 & 42.8 & 40.9 & 43.4 & 47.8 & 48.1 & 48.9 & 47.0 \\
\hline Rtanj & 37.2 & 41.5 & 43.2 & 43.8 & 41.4 & 44.4 & 46.1 & 46.4 & 46.3 & 45.8 & 44.7 & 45.8 & 46.7 & 49.0 & 46.5 \\
\hline Tango & 45.0 & 48.3 & 50.7 & 49.8 & 48.4 & 44.5 & 48.0 & 47.1 & 48.9 & 47.1 & 43.8 & 46.8 & 52.6 & 53.8 & 49.2 \\
\hline Average & 37.3 & 40.7 & 42.0 & 43.6 & 40.9 & 39.6 & 42.1 & 41.3 & 43.0 & 41.5 & 40.4 & 43.2 & 45.7 & 47.5 & 44.2 \\
\hline
\end{tabular}

Table 2. The analysis of variance for 1000 grain weight

\begin{tabular}{|c|c|c|c|c|c|c|c|c|c|c|}
\hline & \multicolumn{4}{|c|}{$2009-2010$} & \multicolumn{3}{|c|}{$2010-2011$} & \multicolumn{3}{|c|}{$2011-2012$} \\
\hline $\begin{array}{l}\text { Source of } \\
\text { variation }\end{array}$ & $\begin{array}{l}\text { Degrees } \\
\text { freedom }\end{array}$ & of Sum of & $\begin{array}{l}\text { Mean sum } \\
\text { of squares }\end{array}$ & $\begin{array}{ll}n & \text { F } \\
s & \end{array}$ & $\begin{array}{l}\text { Sum of } \\
\text { squares }\end{array}$ & $\begin{array}{l}\text { Mean sum } \\
\text { of squares }\end{array}$ & $\mathrm{F}$ & $\begin{array}{l}\text { Sum of } \\
\text { squares }\end{array}$ & $\begin{array}{l}\text { Mean sum } \\
\text { of squares }\end{array}$ & F \\
\hline Replicat. & 2 & 3.826 & 1.913 & 1.510 & 2.073 & 1.037 & 0.761 & 1.460 & 0.730 & 0.631 \\
\hline Treatm. & 19 & 2193.690 & 115.457 & 91.150 & 1598.655 & 84.140 & 61.795 & 2323.199 & 122.274 & 105.697 \\
\hline Factor A & 4 & 1827.354 & 456.838 & $360.659^{44}$ & 1469.241 & 367.310 & $269.766^{* 4}$ & 1814.758 & 453.689 & $392.182^{* *}$ \\
\hline Factor B & 3 & 322.452 & 107.484 & $84.855^{\circ *}$ & 92.909 & 30.970 & $22.745^{\circ *}$ & 430.427 & 143.476 & $124.025^{\circ *}$ \\
\hline$A \times B$ & 12 & 43.883 & 3.657 & $2.887^{\circ *}$ & 36.506 & 3.048 & $2.234^{* *}$ & 78.014 & 6.501 & $5.620^{* *}$ \\
\hline Error & 38 & 48.134 & 1.267 & - & 51.740 & 1.362 & - & 43.960 & 1.157 & - \\
\hline Total & 59 & - & - & - & - & - & - & - & - & - \\
\hline LSD & & 0.05 & & 0.01 & 0.05 & & 0.01 & & .05 & 0.01 \\
\hline $\mathrm{A}$ & & 0.930 & & 1.246 & 0.964 & & 1.292 & & 889 & 1.191 \\
\hline B & & 0.832 & & 1.115 & 0.862 & & 1.156 & & .795 & 1.065 \\
\hline$A \times B$ & & 1.860 & & 2.492 & 1.928 & & 2.584 & & .777 & 2.382 \\
\hline
\end{tabular}

"significant at $0.05 ; "$ " significant at 0.01

From the data in Table 3. it can be noticed that all cultivars had the lowest value of hectolitre weight in control. The application of fertilizers led to a very significant increase in the value of this trait in all three years of the research, while the application of different fertilization variants did not significantly affect this trait. Also, the influence of the year on the observed trait was noticed, since the lowest average value of the hectolitre weight was recorded in the third year, according to climatic conditions, the most unfavourable year. The influence of meteorological factors on this trait was confirmed earlier in the research by Djekić et al. (2009) and Stošović et al. (2010).

Grain yield is the safest indicator of the existence of differences in productivity among varieties and their specificity towards mineral nutrition, because it is precisely the end result of both external factors on the plant and the biorhythmic activity of certain physiological and biochemical processes. The data in the Table 5. show that the use of mineral fertilizers has led to a significantly very high yield increase in all tested cultivars compared to the control.

The research has shown that winter triticale achieves high yields in the use of nitrogen in the amount of $120 \mathrm{~kg} \mathrm{ha}^{-1}$ and phosphorus and potassium in the amount of $80 \mathrm{~kg} \mathrm{ha}^{-1}$, as confirmed by Knapowski et al. (2009) and Pecio (2010), who, in their researches, obtained the highest grain yields when using nitrogen in the amount of $120 \mathrm{~kg} \mathrm{ha}^{-1}$. In the trial run by Bielski (2015) the highest yield was harvested from treatments fertilised with the highest dose of nitrogen (150 kg ha $\left.{ }^{1}\right)$. 
Table 3. Hectolitre weight $(\mathrm{kg})$ per cultivars, fertilizing variants and years

\begin{tabular}{|c|c|c|c|c|c|c|c|c|c|c|c|c|c|c|c|}
\hline \multicolumn{16}{|c|}{ Hectolitre weight $(\mathrm{kg})$} \\
\hline \multirow{3}{*}{$\begin{array}{l}\text { Varieties } \\
\text { (A) }\end{array}$} & \multicolumn{4}{|c|}{$2009-2010$} & \multicolumn{4}{|c|}{$2010-2011$} & \multicolumn{7}{|c|}{$2011-2012$} \\
\hline & \multicolumn{13}{|c|}{ Fertilization variant (B) } & & \\
\hline & 0 & $\mathrm{~N}_{1}$ & $\mathrm{~N}_{2}$ & $\mathrm{~N}_{3}$ & Aver. & 0 & $\mathrm{~N}_{1}$ & $\mathrm{~N}_{2}$ & $\mathrm{~N}_{3}$ & Aver. & 0 & $\mathrm{~N}_{1}$ & $\mathrm{~N}_{2}$ & $\mathrm{~N}_{3}$ & Aver. \\
\hline Odyssey & 65.9 & 76.2 & 76.3 & 73.2 & 72.9 & 66.2 & 70.8 & 67.0 & 68.3 & 68.1 & 65.8 & 67.6 & 69.2 & 69.2 & 68.0 \\
\hline $\mathrm{Kg}-20$ & 61.5 & 67.4 & 66.3 & 68.9 & 66.0 & 69.1 & 69.5 & 70.3 & 71.7 & 70.1 & 64.2 & 65.5 & 63.2 & 62.3 & 63.8 \\
\hline Trumph & 72.5 & 75.7 & 76.6 & 77.5 & 75.6 & 69.2 & 69.5 & 69.9 & 71.6 & 70.0 & 68.6 & 70.5 & 71.4 & 70.3 & 70.2 \\
\hline Rtanj & 68.3 & 69.1 & 71.8 & 71.3 & 70.1 & 65.6 & 64.9 & 66.7 & 68.4 & 66.4 & 67.1 & 67.9 & 64.8 & 65.2 & 66.2 \\
\hline Tango & 73.0 & 72.7 & 72.9 & 73.3 & 73.0 & 63.8 & 65.3 & 64.6 & 66.8 & 65.1 & 67.7 & 69.6 & 68.4 & 71.2 & 69.2 \\
\hline Average & 68.2 & 72.2 & 72.8 & 72.8 & 71.5 & 66.8 & 68.0 & 67.7 & 69.4 & 67.9 & 66.7 & 68.2 & 67.4 & 67.6 & 67.5 \\
\hline
\end{tabular}

Table 4. The analysis of variance for hectolitre weight

\begin{tabular}{|c|c|c|c|c|c|c|c|c|c|c|}
\hline & & \multicolumn{3}{|c|}{$2009-2010$} & \multicolumn{3}{|c|}{$2010-2011$} & \multicolumn{3}{|c|}{$2011-2012$} \\
\hline $\begin{array}{l}\text { Source of } \\
\text { variation }\end{array}$ & $\begin{array}{l}\text { Degrees } \\
\text { freedom }\end{array}$ & $\begin{array}{l}\text { Sum of } \\
\text { squares }\end{array}$ & $\begin{array}{l}\text { Mean sum } \\
\text { of squares }\end{array}$ & n & $\begin{array}{l}\text { Sum of } \\
\text { squares }\end{array}$ & $\begin{array}{c}\text { Mean sum } \\
\text { of squares }\end{array}$ & $\mathrm{F}$ & $\begin{array}{l}\text { Sum of } 1 \\
\text { squares }\end{array}$ & $\begin{array}{c}\text { Mean sum } \\
\text { of squares }\end{array}$ & F \\
\hline Replicat. & 2 & 7.314 & 3.657 & 2.182 & 5.055 & 2.528 & 0.930 & 1.801 & 0.901 & 0.208 \\
\hline Treatm. & 19 & 1000.872 & 52.677 & 31.426 & 337.501 & 17.763 & 6.532 & 400.156 & 21.061 & 4.861 \\
\hline Factor A & 4 & 629.628 & 157.407 & $93.904^{* *}$ & 244.580 & 61.145 & $22.486^{* 4}$ & 304.721 & 76.068 & $17.556^{* *}$ \\
\hline Factor B & 3 & 216.619 & 72.206 & $43.076^{* *}$ & 48.536 & 16.179 & 5.950 & 23.002 & 7.667 & $1.770^{* *}$ \\
\hline $\mathrm{A} \times \mathrm{B}$ & 12 & 154.625 & 12.885 & $7.687^{* *}$ & 44.385 & 3.699 & $1.360^{* *}$ & 72.883 & 6.074 & $1.402^{* *}$ \\
\hline Error & 38 & 63.698 & 1.676 & - & 103.332 & 2.719 & - & 164.649 & 4.333 & - \\
\hline Total & 59 & - & - & - & - & - & - & - & - & - \\
\hline LSD & & 0.05 & & 0.01 & 0.05 & & 0.01 & 0.05 & & 0.01 \\
\hline $\mathrm{A}$ & & 1.070 & & 1.433 & 1.363 & & 1.826 & 1.72 & 20 & 2.305 \\
\hline B & & 0.957 & & 1.282 & 1.219 & & 1.633 & 1.53 & 38 & 2.061 \\
\hline$A \times B$ & & 2.140 & & 2.867 & 2.725 & & 3.651 & 3.44 & & 4.609 \\
\hline
\end{tabular}

"significant at $0.05 ;{ }^{* *}$ significant at 0.01

Table 5. Grain yield ( $\left.\mathrm{tha}^{-1}\right)$ per cultivars, fertilizing variants and years

\begin{tabular}{|c|c|c|c|c|c|c|c|c|c|c|c|c|c|c|c|}
\hline \multicolumn{16}{|c|}{ Grain yield (t ha- $\left.{ }^{-1}\right)$} \\
\hline \multirow{3}{*}{$\begin{array}{l}\text { Varieties } \\
\text { (A) }\end{array}$} & \multicolumn{5}{|c|}{$2009-2010$} & \multicolumn{5}{|c|}{$2010-2011$} & \multicolumn{5}{|c|}{$2011-2012$} \\
\hline & \multicolumn{13}{|c|}{ Fertilization variant (B) } & & \\
\hline & $\begin{array}{c}0 \\
\text { Aver. }\end{array}$ & $\mathrm{N}_{1}$ & $\mathrm{~N}_{2}$ & $\mathrm{~N}_{3}$ & Aver. & 0 & $\mathrm{~N}_{1}$ & $\mathrm{~N}_{2}$ & $\mathrm{~N}_{3}$ & Aver. & 0 & $\mathrm{~N}_{1}$ & $\mathrm{~N}_{2}$ & $\mathrm{~N}_{3}$ & \\
\hline Odyssey & 4.31 & 5.43 & 5.53 & 6.28 & 5.39 & 3.75 & 5.03 & 5.24 & 5.49 & 4.88 & 3.12 & 4.94 & 5.02 & 5.23 & 4.58 \\
\hline $\mathrm{Kg}-20$ & 3.74 & 4.52 & 5.45 & 5.28 & 4.75 & 3.12 & 4.61 & 4.73 & 4.86 & 4.33 & 2.99 & 4.54 & 4.42 & 4.45 & 4.10 \\
\hline Triumph & 4.11 & 5.28 & 6.13 & 6.25 & 5.44 & 3.66 & 5.21 & 5.81 & 5.88 & 5.14 & 3.23 & 5.01 & 4.84 & 4.90 & 4.49 \\
\hline Rtanj & 3.87 & 5.02 & 5.93 & 6.00 & 5.20 & 3.59 & 5.57 & 5.68 & 6.24 & 5.27 & 3.34 & 4.97 & 5.11 & 5.22 & 4.66 \\
\hline Tango & 4.17 & 5.64 & 6.73 & 7.14 & 5.92 & 3.96 & 6.03 & 6.39 & 6.73 & 5.78 & 3.40 & 5.14 & 5.21 & 5.29 & 4.76 \\
\hline Average & 4.04 & 5.18 & 5.95 & 6.19 & 5.34 & 3.62 & 5.29 & 5.57 & 5.84 & 5.08 & 3.22 & 4.92 & 4.92 & 5.02 & 4.52 \\
\hline
\end{tabular}

Table 6. The analysis of variance for grain yield

\begin{tabular}{|c|c|c|c|c|c|c|c|c|c|c|}
\hline & & \multicolumn{3}{|c|}{$2009-2010$} & \multicolumn{3}{|c|}{$2010-2011$} & \multicolumn{3}{|c|}{$2011-2012$} \\
\hline $\begin{array}{l}\text { Source of } \\
\text { variation }\end{array}$ & $\begin{array}{l}\text { Degrees of } \\
\text { freedom }\end{array}$ & $\begin{array}{l}\text { Sum of } \\
\text { squares }\end{array}$ & $\begin{array}{l}\text { Mean sum } \\
\text { of squares }\end{array}$ & $\mathrm{F}$ & $\begin{array}{l}\text { Sum of } \\
\text { squares }\end{array}$ & $\begin{array}{l}\text { Mean sum } \\
\text { of squares }\end{array}$ & $\mathrm{F}$ & $\begin{array}{l}\text { Sum of } \\
\text { squares }\end{array}$ & $\begin{array}{l}\text { Mean sum } \\
\text { of squares }\end{array}$ & $F$ \\
\hline Replicat. & 2 & 0.429 & 0.215 & 3.093 & 0.159 & 0.080 & 0.429 & 1.621 & 0.811 & 2.587 \\
\hline Treatm. & 19 & 53.122 & 2.796 & 40.284 & 61.245 & 3.223 & 17.380 & 37.714 & 1.985 & 6.334 \\
\hline Factor A & 4 & 7.341 & 1.835 & $26.443^{* *}$ & 11.588 & 2.897 & $15.620^{* *}$ & 3.105 & 0.776 & $2.477^{*}$ \\
\hline Factor B & 3 & 42.527 & 14.176 & $204.246^{* *}$ & 47.288 & 15.763 & $84.988^{\circ *}$ & 34.106 & 11.369 & $36.277^{* 4}$ \\
\hline$A \times B$ & 12 & 3.254 & 0.271 & $3.908^{* *}$ & 2.368 & 0.197 & $1.064^{* *}$ & 0.502 & 0.042 & $0.133^{* *}$ \\
\hline Error & 38 & 2.637 & 0.069 & - & 7.048 & 0.185 & - & 11.909 & 0.313 & - \\
\hline Total & 59 & - & - & - & - & - & - & - & - & - \\
\hline LSD & & 0.05 & & 0.01 & 0.0 & 05 & 0.01 & & 0.05 & 0.01 \\
\hline $\mathrm{A}$ & & 0.21 & & 0.292 & 0.35 & 56 & 0.477 & & 0.463 & 0.620 \\
\hline B & & 0.19 & & 0.261 & 0.31 & & 0.426 & & 0.414 & 0.554 \\
\hline$A \times B$ & & 0.43 & & 0.583 & 0.71 & 12 & 0.954 & & 0.925 & 1.240 \\
\hline
\end{tabular}


The greatest impact on the yield and yield structure had the years during which the experiment was carried out, followed by cultivar and distribution of nitrogen fertilization dosing (Alaru et al. 2004). The positive effects of mineral nutrition, especially nitrogen, on the grain yield of triticale were pointed out earlier and by other authors (Bojović 2010; Lestingi et al. 2010). As a result of the influence of various climatic factors, variation in yields by the years of testing was also noted. The highest grain yield was recorded in the vegetation year 2009/10, which was the most favourable in terms of quantity and precipitation. The unfavourable weather conditions for the cultivation of winter triticale in the third year of the study had a negative impact on the yield level in relation to the previous two years. Significantly smaller amounts of precipitation in the last three months of the year, which are important for planting and initial development of plants, resulted in later incomplete emergence. Also, the heavy snowfall in February 2012, as well as the long retention of snow cover led to a slowdown of vegetation in spring, later sowing and flowering. The high air temperatures in June and July, in the same year, caused a shortening of the period of filling of the grain, accelerated ripening and reduction of the yield.

The results of this study showed that the influence of nitrogen fertilization on the grain yield, components of the yield and the quality of grain, do not depend only on the dose of fertilizers, but also on the climatic conditions, as Janušauskaitè (2013), Ivanova and Kirchev (2014), Djurić et al. (2015), Madić et al. (2018), Terzić et al. (2018) and Đekić et al. (2019) had confirmed previously in their researches. (Djekić et al. 2012; 2014), as well as many other authors, point out that the high quality of grain and the best triticale yields are obtained in the years with warm bright spring weather conditions and cold summers without excessive precipitation during the grain filling stage, which is in agreement with this study.

\section{CONCLUSIONS}

The results of this study showed that the values of the examined productive traits of the genotypes of winter triticale varied depending on the applied dose of nitrogen, weather conditions and cultivar. On average over the three-year period of the study, the $\mathrm{N}_{3}$ variant of fertilization had the greatest positive effect on most parameters affecting productivity. The cultivar Tango had the highest average yield (5.49 $\left.\mathrm{t} \mathrm{ha}^{-1}\right)$ while $\mathrm{Kg}-20$ had the lowest $\left(4.39 \mathrm{t} \mathrm{ha}^{-1}\right)$. Also, Tango had the highest value of 1000 grain weight, while Triumph had the highest value of hectolitre weight. The differences in yields that have been shown in the cultivars included in the research are the result of varietal specificity, which is largely genetically conditioned. The results of the research can be of great importance for the popularization of triticale as a species in this production area for the improvement of production practice in Montenegro and beyond. Also, the results are important for cattle-oriented farms, where the main priority is to ensure a sufficient amount of quality food. 


\section{REFERENCES}

Alaru, M., Möller, B., Hansen, Ă. (2004). Triticale yield formation and quality influenced by different $\mathrm{N}$ fertilisation regimes. Agronomy Research, 2 (1): 3-12.

Biberdžić, M., Jelić, M., Deletić, N., Barać, S., Stojković, S., Stanković, S., Stamenković, S. (2011). The effect of fertilization system on weed infestation and grain yield of small grains on acid soils. Research Journal of Agricultural Science, 43 (1): 3-8.

Biberdžić, M., Jelić, M., Knežević, B., Stojković, S., Lalević, D. (2012). Grain yield of triticale and rye in dependence on acid soils fertilization, International Symposium for Agriculture and Food, Skopje, Macedonia, Book of Proceedings, Section 1: Field Crop Production, p. 26-32.

Bielski, S. (2015). Yields of winter triticale under the influence of nitrogen fertilisation and fungicide application. Polish journal of natural sciences. Polish Journal of Natural Sciences, 30 (4): 337-348.

Bojović, B. (2010). Influence of mineral nutrition on some parameters of productivity wheat and triticale cultivars. PhD, University in Kragujevac, p. 112, 116. (in Serbian)

Djekić, V., Glamočlija, Đ., Staletić, M., Perišić, V. (2009). Variability of grain yield and yield components of $\mathrm{Kg}$ winter triticale cultivars. Journal of Scientific Agricultural Research, 70 (3): 55-60.

Djekić, V., Milovanović, M., Staletić, M., Perišić, V. (2010). Investigation of yield components Kragujevac varieties winter triticale. Proceedings of research papers, 16 (1-2): 35-41.

Djekić, V., Popović, V., Milivojević, J., Branković, S. (2012). Variability of yield and grain yield components of KG winter triticale varieties. Bulletin of the alternative plant species, 44 (85): 13-20.

Djekić, V., Milovanović, M., Popović, V., Milivojević, J., Staletić, M., Jelić, M., Perišić, V. (2014). Effects of fertilization on yield and grain quality in winter triticale. Romanian Agricultural Research, 31: 175-183.

Đekić, V., Popović, V., \& Terzić, D. (2019). Grain Production and quality components of winter triticale in semi-arid conditions. Chapter 6. Ed. Janjev. I. Book Title: Serbia: Current Issues and Challenges in the Areas of Natural Resources, Agriculture and Environment. NOVA Science publishers, INC., (pp. 149-170). USA, ISBN: 978-1-53614-897-8.

Djurić, N., Trkulja, V., Simić, D., Prodanović, S., Djekić, V., Dolijanović, Ž. (2013). Analysis grain yield and quality of some cultivars of winter wheat in 2011-2012 year. Proceedings of Research papers of Institute PKB Agroeconomic, 19 (1-2): 15-21.

Djurić, N., Cvijanović, G., Dozet, G., Matković, M., Djekić, V., Trkulja, V. (2015). New winter triticale species developed at Institute PKB Agroekonomik. Plant Breeding and Seed Production, 21 (1), 10-17.

Epure, L.I., Ion, V., Basa, A. Gh., Dumbrava, M., Epure, D. G., Temocico, G. (2015). Results regarding the biomass yield at triticale under different technological conditions. Proceedings of $6^{\text {th }}$ international scientific agricultural symposium AGROSYM 2015, p. 273-278.

Estrada-Campuzano, G. Slafer, G. A., Miralles, D. J. (2012). Differences in yield, biomass and their components between triticale and wheat grown under contrasting water and nitrogen environments. Field Crops Research, 128: 167-179. 
Fraś, A., Gotȩbiewska, K., Gotȩbiewski, D., Mańkowski, D.R., Boros, D., \& Szecówka, P. (2016): Variability in the chemical composition of triticale grain, flour and bread. J. Cereal Sci. 71: 66-72.

Ivanova, A., Kirchev, H. (2014). Agronomy performance of new triticale varieties (xTriticosecale Wittm.) grown under different regions. Global Journal of Scientific Researches, 2 (3), 71-75.

Janušauskaitė, D. (2013). Spring triticale yield formation and nitrogen use efficiency as affected by nitrogen rate and its splitting. Zemdirbyste-Agriculture, 100 4: 383392.

Jaćimović, G., Malešević, M., Marinković, B., Crnobarac, J., Latković, D., Šeremešić, S., Milošev, D. (2008). Components of wheat yields depending on the level of fertilization with nitrogen, phosphorus and potassium. Yearbook of scientific papers, Faculty of Agriculture Novi Sad, Serbia, 32: 57-63.

Jelić, M., Djekić, V., Milivojević, J., Dugalić, G., Madić, M. (2013). Yield stability parameters triticale on acid soils. Proceedings, Faculty of Agronomy. Čačak, Serbia. 18 (20): 93-98.

Kendal, E. and M.S. Sayar (2016): The stability of some spring triticale genotypes using biplot analysis. The J. Anim. Plant Sci. 26(3): 754-765.

Knapowski, T., Ralcewicz, M., Barczak, B., Kozera, W. (2009). Effect of nitrogen and zinc fertilizing on bread-making quality of spring triticale cultivated in Notec Valley. Polish Journal of Environmental Studies, 18 (2): 227-233.

Lestingi, A., Bovera, F., De Gorgio, D., Ventrella, D., Tateo, A. (2010). Effect of tillage and nitrogen fertilization on triticale grain yield, chemical composition and nutritive value, Journal of the Science of Food and Agriculture, 90: 2440-2446.

Madić, M., Paunović, A., Djurović, D., Marković, G., Knežević, D., Jelić, M., Stupar, V. (2018). Grain yield and its components in triticale grown on a pseudogley soil, Journal of Central European Agriculture, 19 (1), p.184-193.

Pecio, A. (2010). Productivity of triticale affected by nitrogen fertilization and weather conditions. Fertilizer and fertilization, 40: 101-116.

Popović, V., Glamočlija, Đ., Malešević, M., Ikanović, J., Dražić, G., Spasić, M., Stanković, S. (2011). Genotype specificity in nitrogen nutrition of malting barley. Genetika, Belgrade,Serbia 43 (1): 197-204.

Rajičić, V., Milivojević, J., Popović, V., Branković, S., Đurić N., Perišić, V., Terzić, D. (2019). Winter wheat yield and quality depending on the level of nitrogen, phosphorus and potassium fertilization. Agriculture and Forestry, 65(2): 79-88

Stošović, D. (2009). A comparative research of the major characteristics of barley and triticale under the agro-ecological conditions in the north of Montenegro, Master thesis, Faculty of Agriculture, University in Pristina, Kosovska Mitrovica, p. 37, 67. (in Serbian)

Stošović, D., Biberdžić, M., Deletić, N., Jelić, M., Paunović, A. (2010). Grain yield and quality of triticale and barley obtained in comparative production. XII International Symposium on Forage Crops of Republic of Serbia, Biotechnology in animal husbandry, 26 (spec. issue): 635-640.

Terzic, D., Djekic, V., Jevtic, S., Popovic, V., Jevtic A., Mijajlovic, J., \& Jevtic, A. (2018). Effect of long-term fertilization on grain yield and yield components in winter triticale. The Journal of Animal and Plant Sciences. 28, 3, 830-836.

Yugoslav Society for Soil Studies (1966). Chemical methods of soil testing. Land Survey Manual, Book I, Belgrade. 